\title{
GERMINATION RESPONSES OF SOME FORAGE SPECIES OF EASTERN TERAI, NEPAL
}

\author{
S.N. Jha and P.K. Jha \\ Central Department of Botany \\ Tribhuvan University, Kirtipur, Kathmandu, Nepal \\ E-mail: pkjha@ecos.wlink.com.np
}

\begin{abstract}
Freshly harvested seeds of the test species (legumes: Alysicarpus vaginalis and Desmodium triflorum; grasses: Axonopus compressus and Chrysopogon aciculatus) failed to germinate even after acid scarification and incubation under different light qualities, whereas seven-nine-month old seeds exhibited germination in the order: D. triflorum $(23 \%)>A$. compressus $(17 \%)>A$. vaginalis $(13 \%)>$ C. aciculatus ( $4 \%$ ) without acid scarification or nutrient treatment. The legumes contained yellowishbrown $(\mathrm{Yb})$ and brick-red $(\mathrm{Br})$ seeds in their pods in the ratio of 4:1. The $\mathrm{Yb}$ seeds had hard seed covering very slowly permeable to water. Storage of seeds under room conditions in sealed polythene pouches up to three years profoundly inhibited germination in $\mathrm{Br}$ seeds but had little effect on $\mathrm{Yb}$ seeds. The nine-month-old $\mathrm{Br}$ seeds had maximum germination (24 and $38 \%$, respectively in $A$. vaginalis and $D$. triflorum) when submerged in water for $24 \mathrm{~h}$ before sowing, whereas germination in $\mathrm{Yb}$ seeds of the same age was 72 and $77 \%$, respectively in A. vaginalis and D. triflorum when submerged in water for three days as a pretreatment. Germination in mixed $(\mathrm{Yb}$ and $\mathrm{Br})$ seed lot was $71 \%$ in A. vaginalis and $84 \%$ in D. triflorum when seven-eight-month old seeds were scarified with sulphuric acid for $10 \mathrm{~min}$ and incubated under red light for a week. The fresh seeds of $A$. compressus had $79 \%$ viability (TTC test) which declined to $5 \%$ after storage for three years, and nine-month-old caryopses when treated with nitric acid for ten minute and incubated under red light for 18 days had maximum ( $45 \%$ ) germination. In C. aciculatus. seeds had only $37 \%$ viability when fresh, and they completely lost viability after storage for two years, and nine-month old caryopses had maximum (17\%) germination when treated with $0.5 \%$ solution of potassium nitrate and incubated under ordinary condition for 25 days.
\end{abstract}

Key words: Seed attributes, storage, viability, acid scarification, light, imbibition, potassium nitrate.

\section{INTRODUCTION}

Among the forage species in the grazing fields at Biratnagar (latitude N $26^{\circ} 20^{\prime}$, longitude $87^{\circ} 16^{\prime}$, altitude $72 \mathrm{~m}, \mathrm{msl})$, Chrysopogon aciculatus and Axonopus compressus are the most abundant grasses, and Desmodium triflorum and Alysicarpus vaginalis are their associated legumes (Jha and Jha 2000). All these species are weak perennials. They have prostrate forms, and, in addition to sexual reproduction, they also propagate vegetatively.

The pods of $A$. vaginalis and $D$. triflorum contain two types of seeds: (i) yellowish-brown $(\mathrm{Yb})$ and (ii) brick-red $(\mathrm{Br})$ in the ratio of 4:1 (Jha et al. 1999). Caryopses of A. compressus are smooth to touch but firmly enclosed by awnless lemma and palea; whereas caryopses of 
C. aciculatus are rough to touch, loosely enclosed by glumes, and bear an awned (average length 5 $\mathrm{mm}$ ) lemma. The term "seed" used in this text also denotes caryopses (fruits) of the grass species as pericarp and seed coat layer are contaguous in caryopsis and therefore inseparable from the standpoint of seed handling.

Seed maturation and dispersal occur throughout the year in A. compressus, October to May in C. aciculatus, December to May in $A$. vaginalis and November to May in D. triflorum. Seed germination and seedling emergence in legumes take place mainly in early summer (March) whereas grasses germinate in late June to early July after arrival of the monsoon season.

The objectives of this study were: (i) to record the physical attributes (length, breadth, weight, etc) and impact of various storage durations on seed viability, and (ii) to investigate germination responses of seeds to acid scarification, different light qualities (colours), various submergence durations in water, and concentrations of potassium nitrate to understand the fundamentals of germination ecology of the aforesaid forage species under laboratory conditions.

\section{MATERIALS AND METHODS}

Seed source and physical attributes: Seeds of each species were collected from a single population occurring within the premises of Post Graduate Campus, (Tribhuvan University), Biratnagar. Climate of Biratnagar is tropical and monsoonic and the soil has slightly acidic nature. The average annual rainfall is $1730 \mathrm{~mm}$, being maximum $(1505 \mathrm{~mm} / 87 \%)$ in rainy season. The grass seeds were collected in October and those of legumes in December 1997. Seeds were dried in shade for seven-eight days and stored in hermetically sealed polythene pouches (Copeland 1976) under ordinary storage condition at room temperature for subsequent germination studies.
Seed output per unit area was measured according to the method of Zobel et al. (1987). The seed/caryopsis size was measured microscopically through a micrometer whereas seed/caryopsis weight was determined by using an electric balance.

Seed viability: The seed coverings were removed manually and the decoated seeds of the grass species were soaked in distilled water and kept in dark for $24 \mathrm{~h}$ before being treated with $0.1 \%$ solution of 2, 3, 5-triphenyltetrazolium chloride (TTC) for assessing the effects of various durations of storage on viability (Misra 1968). On the other hand, germination test was the criterion for viability in the legume seeds.

Germination test: Germination was evaluated between June to September in Petri dishes $(4.5 \mathrm{~cm}$ diam.) on filter paper saturated with distilled water. Moisture was maintained by daily monitoring, with distilled water added as needed, and germination was defined as radicle emergence. All sets of treatment and control contained four replicates, each of 25 seeds. The petri dishes were placed on a table in the laboratory at room temperature which, in addition to diffuse light entering the laboratory through glass windows from dawn to dusk, received light for eight h (between 9 am and $5 \mathrm{pm}$ ) daily from a $40 \mathrm{~W}$ fluorescent tube fixed in the lab ceiling at $1.5 \mathrm{~m}$ distance from the table surface. Seeds in light were inspected everyday and the germinated seeds were counted and discarded, whereas those incubated in dark were not inspected until germination under light became static. The average daily maximum and minimum room temperatures during the experiment were 30 and $20^{\circ} \mathrm{C}$, respectively.

Since seeds of all the forage species responded poorly to soaking in water alone for germination, the mixed seeds $(\mathrm{Yb}$ and $\mathrm{Br})$ of legumes were treated with concentrated sulphuric acid, whereas caryopses of $A$. compressus were treated with 
concentrated nitric acid (treatment with sulphuric acid had deleterious effect on seed) to see if the seed covering was hampering imbibition and germination of seeds. The seeds were treated with acid for 5, 10 and 15 minute after which they were rinsed under running water for a minute to remove the acid, and sown. For the study of germination response of seeds to different light qualities, Petri dishes were covered by red and blue cellophane papers separately. Seeds were also incubated under white light as well as in complete darkness (by covering the Petri dishes with black carbon sheet).

Caryopses of C. aciculatus were soaked in distilled water for $24 \mathrm{~h}$, and then treated with 0.25 $1 \%$ solution of potassium nitrate to enhance germination, and sown under ordinary condition (as seeds did not respond to acid/light treatments).

To study the germination response of legume seeds to submergence in water for various durations (this test had no noticeable effect on germination of grass seeds), adequate amount of $\mathrm{Yb}$ and $\mathrm{Br}$ seeds were placed separately in $500 \mathrm{ml}$ beaker which was subsequently filled with water five times more than the volume of seeds, and kept as such for six days except that the required amount of submerged seeds were taken out from the beaker at the specified time intervals and sown in Petridishes under ordinary condition.
Germination count was made seven days after sowing in each set of experiment.

\section{RESULTS AND DISCUSSION}

Seed attributes: The forage species had seed set per plant in the order: $A$. compressus $(64)>D$. triflorum $(56)>A$. vaginalis $(55)>C$. aciculatus (30), whereas order of seed production per unit area $\left(\mathrm{m}^{2}\right)$ was: $C$. aciculatus $(17340)>A$. compressus $(12480)>D$. triflorum $(1176)>A$. vaginalis $(880)$ at the seed collection site (Table $1)$.

The caryopses of A. compressus were yellowish-brown in colour and oval in shape. The average length and breadth of the caryopses were 0.41 and $0.21 \mathrm{~mm}$, respectively. Weight of 1000 air-dried, and water imbibed ( $24 \mathrm{~h}$ ) caryopses were 0.36 and $1.06 \mathrm{~g}$, respectively; and the weight of 1000 caryopses after treatment with nitric acid for $10 \mathrm{~min}$ followed by water imbibition for $24 \mathrm{~h}$ was $1.22 \mathrm{~g}$.

The spindle-shaped caryopses of $C$. aciculatus were brownish-red in colour, $3 \mathrm{~mm}$ in length and 1 $\mathrm{mm}$ in breadth. Weight of 1000 air-dried, and water imbibed $(24 \mathrm{~h})$ caryopses were 0.52 and 1.89 $\mathrm{g}$, respectively; and the weight of 1000 caryopses after treatment with nitric acid for $10 \mathrm{~min}$ followed by water imbibition for $24 \mathrm{~h}$ was $2.01 \mathrm{~g}$.

Table 1. Seed output (mean \pm standard error) of the forage species.

\begin{tabular}{|c|c|c|c|c|c|c|}
\hline Species & $\begin{array}{c}\text { Date of } \\
\text { observation }\end{array}$ & $\begin{array}{c}\text { No. of } \\
\text { seeds/fruit } \\
(\mathrm{n}=25) \\
\end{array}$ & $\begin{array}{c}\text { No. of } \\
\text { fruits/plant } \\
(n=25)\end{array}$ & $\begin{array}{c}\text { Seed } \\
\text { output/plant } \\
(n=25)\end{array}$ & $\begin{array}{c}\text { Plant } \\
\text { density } / \mathrm{m}^{2} \\
(\mathrm{n}=10)\end{array}$ & $\begin{array}{c}\text { Seed } \\
\text { production } / \mathrm{m}^{2}\end{array}$ \\
\hline Alysicarpus vaginalis & December 19, 1997 & $5.0 \pm 1.0$ & $11.0 \pm 1.0$ & $55.0 \pm 1.0$ & $16.0 \pm 1.0$ & $880 \pm 9.0$ \\
\hline Axonopus compressus & October 13, 1997 & 1.0 & $64.0 \pm 2.0$ & $64.0 \pm 2.0$ & $195.0 \pm 4.0$ & $12480 \pm 35.0$ \\
\hline Chrysopogon aciculatus & September 22, 1997 & 1.0 & $30.0 \pm 1.0$ & $30.0 \pm 1.0$ & $578.0 \pm 8.0$ & $17340 \pm 42.0$ \\
\hline Desmodium triflorum & December 2, 1997 & $4.0 \pm 1.0$ & $14.0 \pm 1.0$ & $56.0 \pm 2.0$ & $21.0 \pm 1.0$ & $1176 \pm 11.0$ \\
\hline
\end{tabular}


In A. vaginalis, the average length of $\mathrm{Yb}$ and Br seeds were 0.36 and $0.38 \mathrm{~mm}$, respectively, and average breadth 0.24 and $0.29 \mathrm{~mm}$, respectively. Weight of 1000 air-dried $\mathrm{Yb}$ and $\mathrm{Br}$ seeds was 1.35 and $1.40 \mathrm{~g}$, respectively. There was only $14.8 \%$ (i.e. $0.2 \mathrm{~g}$ ) increase in weight of $1000 \mathrm{Yb}$ seeds in contrast to $88.6 \%$ (i.e. $1.24 \mathrm{~g}$ ) increase in $1000 \mathrm{Br}$ seeds after imbibing water for $24 \mathrm{~h}$. Weight of $1000 \mathrm{Yb}$ seeds after acid scarification for $10 \mathrm{~min}$ followed by water imbibition for $24 \mathrm{~h}$ increased by $85.8 \%$ (i.e. $1.33 \mathrm{~g}$ ) in comparison to water imbibition without scarification. Similar treatment increased the weight of $\mathrm{Br}$ seeds by only $12.1 \%$ (i.e. $0.32 \mathrm{~g}$ ) (Table 2).

In D. triflorum, the length of $\mathrm{Yb}$ and $\mathrm{Br}$ seeds were 0.36 and $0.37 \mathrm{~mm}$, respectively whereas averge breadth was 0.29 and $0.31 \mathrm{~mm}$, respectively. Weight of 1000 air-dried $\mathrm{Yb}$ and $\mathrm{Br}$ seeds was 1.56 and $1.61 \mathrm{~g}$, respectively, and weight of $1000 \mathrm{Yb}$ seeds after water imbibition for $24 \mathrm{~h}$ increased by $5.8 \%$ only, whereas this increase was $73.9 \%$ in $\mathrm{Br}$ seeds. Scarification with acid for $10 \mathrm{~min}$ followed by water imbibition for $24 \mathrm{~h}$ increased the weight of $1000 \mathrm{Yb}$ seeds by $84.8 \%$ and those of $\mathrm{Br}$ seeds by $7.1 \%$ in comparison to water imbibition without scarification.

In general, water imbibition by acid scarified $\mathrm{Yb}$ seeds increased up to nearly $85 \%$ in comparison to water imbibition by non-scarified seeds in both the legumes, whereas in $\mathrm{Br}$ seeds such an increase was only $12.1 \%$ in $A$. vaginalis and $7.1 \%$ in $D$. triflorum indicating very slow permeability of water through the seed coat in $\mathrm{Yb}$ seeds. On the other hand, water imbibition by acid scarified caryopses increased by only $6.3 \%$ in $C$. aciculatus, and by $15 \%$ in $A$. compressus in comparison to water imbibition without acid scarification (Table 2).

Seed viability: TTC test indicated $79 \%$ viability in freshly harvested seeds of $A$. compressus. Seed viability deteriorated as storage duration increased, and after storage for three years, only $5 \%$ viability was recorded (Table 3). Freshly harvested seeds of C. aciculatus had only $37 \%$ viability, and they became non-viable after storage for two years.

Table 2. Seed/caryopsis characters (mean \pm standard error) of the forage species.

\begin{tabular}{|c|c|c|c|c|c|c|}
\hline \multirow{3}{*}{$\begin{array}{l}\text { Parameters } \\
\text { 1. Colour }\end{array}$} & \multicolumn{4}{|c|}{ Legumes } & \multicolumn{2}{|c|}{ Grasses } \\
\hline & \multicolumn{2}{|c|}{ A. vaginalis } & \multicolumn{2}{|c|}{ D. triflorum } & \multirow{2}{*}{$\begin{array}{c}\text { A. compressus } \\
\text { Yellowish- } \\
\text { brown (Yb) }\end{array}$} & \multirow{2}{*}{$\begin{array}{c}\text { C. aciculatus } \\
\text { Brownish-red } \\
\text { (Br) }\end{array}$} \\
\hline & $\begin{array}{l}\text { Yellowish- } \\
\text { brown }(\mathrm{Yb})\end{array}$ & Brick-red (Br) & $\begin{array}{l}\text { Yellowish- } \\
\text { brown (Yb) }\end{array}$ & Brick-red (Br) & & \\
\hline 2. Shape & Kidney shaped & Kidney shaped & Kidney shaped & Kidney shaped & Oval & Spindle shaped \\
\hline 3. Length $(\mathrm{mm})(\mathrm{n}=20)$ & $0.36 \pm 0.13$ & $0.38 \pm 0.14$ & $0.36 \pm 0.13$ & $0.37 \pm 0.14$ & $0.41 \pm 0.14$ & $3.0 \pm 0.39$ \\
\hline 4. Breadth $(\mathrm{mm})(\mathrm{n}=20)$ & $0.24 \pm 0.11$ & $0.29 \pm 0.12$ & $0.29 \pm 0.12$ & $0.31 \pm 0.12$ & $0.21 \pm 0.10$ & $1.0 \pm 0.22$ \\
\hline $\begin{array}{l}\text { 5. Weight }(\mathrm{g}) \text { of } 1000 \text { air- } \\
\text { dried seeds }\end{array}$ & $1.35 \pm 0.67$ & $1.40 \pm 0.68$ & $1.56 \pm 0.72$ & $1.61 \pm 0.73$ & $0.36 \pm 0.35$ & $0.52 \pm 0.42$ \\
\hline $\begin{array}{c}\text { 6. Weight }(\mathrm{g}) \text { of } 1000 \\
\text { water imbibed seeds }\end{array}$ & $1.55 \pm 0.72$ & $2.64 \pm 0.94$ & $1.65 \pm 0.74$ & $2.80 \pm 0.97$ & $1.06 \pm 0.59$ & $1.89 \pm 0.79$ \\
\hline $\begin{array}{l}\text { 7. Weight (g) of } 1000 \\
\text { acid scarified seeds } \\
\text { allowed to imbibe } \\
\text { water for } 24 \mathrm{~h}\end{array}$ & $2.88 \pm 0.98$ & $2.96 \pm 0.99$ & $3.05 \pm 1.00$ & $3.00 \pm 1.00$ & $1.22 \pm 0.64$ & $2.01 \pm 0.82$ \\
\hline
\end{tabular}


Table 3. Effects of various storage durations on seed viability (\%) (mean \pm standard error) of the forage species.

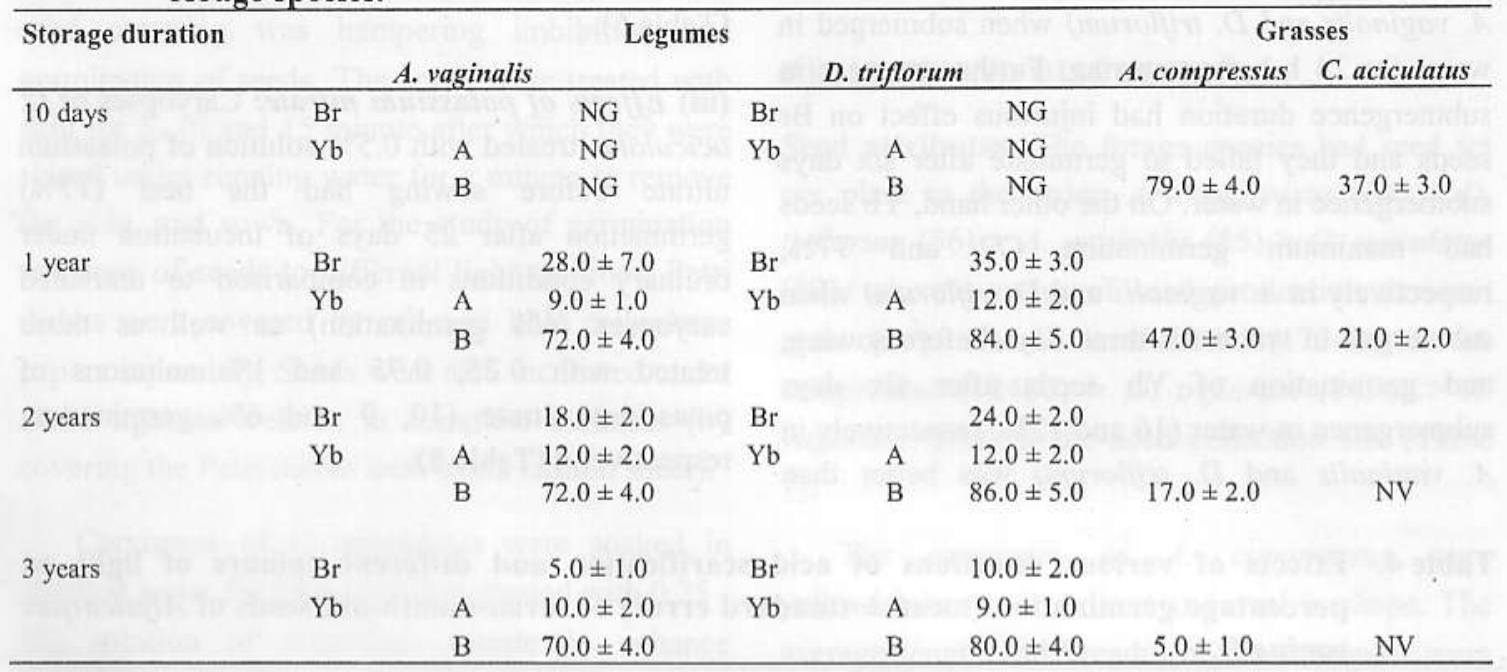

$\mathrm{NG}=$ not germinated, $\mathrm{NV}=$ non-viable, $\mathrm{Br}=$ brick-red seeds (germination without acid scarification). $\mathrm{Yb}=$ yellowish-brown seeds, $\mathrm{A}=$ germination without acid scarification, $\mathrm{B}=$ germination after acid scarification .

Freshly harvested seeds (both $\mathrm{Yb}$ and $\mathrm{Br}$ ) of the legumes did not germinate even after acid scarification. The $\mathrm{Br}$ seeds had maximum germination $(28$ and $31 \%$ in $A$. vaginalis and $D$. triflorum, respectively) after storage for one year, and minimum germination (5 and $10 \%$, respectively in $A$. vaginalis and $D$. triflorum) after storage for three years. The non-scarified $\mathrm{Yb}$ seeds of both the legumes had maximum germination $(12 \%)$ after storage for two years. The Yb seeds stored for one and three years had more or less similar percentage of germination ( 9 and $10 \%$, respectively) in $A$. vaginalis, but germination declined slightly in D. triflorum after storage for three years. Acid scarified $\mathrm{Yb}$ seeds had maximum germination $(72 \%)$ after storage for one and two years in $A$. vaginalis, whereas in D. triflorum maximum germination $(86 \%)$ was recorded after storage for two years (Table 3 ).

\section{Germination responses}

(i) Acid scarification and light treatments: In general, seven-nine-month old seeds of $A$. vaginalis, $D$. triflorum and $A$. compressus without acid scarification had poor germination than those scarified with concentrated sulphuric/ nitric acid for 5, 10 and 15 min (Tables 4, 5, 7). Further, seeds scarified with sulphuric/nitric acid for $10 \mathrm{~min}$ showed better germination than those scarified with acid for 5 and $15 \mathrm{~min}$. Among the light qualities, red light had promotive while blue light and dark condition had inhibitory effects on percentage germination of the said species.

Germination in $A$. vaginalis was maximum $(71 \%)$ when mixed $(\mathrm{Yb}$ and $\mathrm{Br})$ seeds were scarified with concentrated sulphuric acid for 10 min and incubated in red/white light for a week (Table 4). Acid scarified (for $10 \mathrm{~min}$ ) mixed seeds of $D$. triflorum incubated under white and red light conditions for eight days had 81 and $84 \%$ germination, respectively (Table 5). Similarly, caryopses of $A$. compressus treated with concentrated nitric acid for $10 \mathrm{~min}$ before being incubated under different light qualities had maximum (45\%) germination in red light, and 41 , 42 and $37 \%$ germination under white light, blue light and dark condition, respectively after 18 days of incubation (Table 7).

(ii) Submergence in water: Submergence in water for various durations (up to six days) had contrasting effects on germination in $\mathrm{Yb}$ and $\mathrm{Br}$ 
seeds of the legume species. Germination in $\mathrm{Br}$ seeds was maximum ( 34 and $38 \%$, respectively in $A$. vaginalis and $D$. triflorum) when submerged in water for $24 \mathrm{~h}$ before sowing. Further increase in submergence duration had injurious effect on $\mathrm{Br}$ seeds and they failed to germinate after six days submergence in water. On the other hand, $\mathrm{Yb}$ seeds had maximum germination ( 72 and $77 \%$, respectively in $A$. vaginalis and $D$. triflorum) when submerged in water for three days before sowing; and germination of $\mathrm{Yb}$ seeds after six days submergence in water (16 and $12 \%$, respectively in $A$. vaginalis and $D$. triflorum) was better than submergence of seeds in water for $1 \mathrm{~h}(9$ and $11 \%$, respectively in $A$. vaginalis and $D$. triflorum) only (Table 6).

(iii) Effects of potassium nitrate: Caryopses of $C$. aciculatus treated with $0.5 \%$ solution of potassium nitrate before sowing had the best $(17 \%)$ germination after 25 days of incubation under ordinary conditions in comparison to untreated caryopses ( $4 \%$ germination) as well as those treated with $0.25,0.75$ and $1 \%$ solutions of potassium nitrate $(10,9$ and $6 \%$ germination, respectively) (Table 8 ).

Table 4. Effects of various durations of acid scarification and different colours of light on percentage germination (mean \pm standard error) of seven-month-old seeds of Alysicarpus vaginalis.

\begin{tabular}{|c|c|c|c|c|c|c|c|c|c|c|c|c|c|c|c|c|c|c|c|}
\hline \multirow{3}{*}{$\begin{array}{l}\text { Treat } \\
\text { ments }\end{array}$} & \multicolumn{19}{|c|}{ Days after sowing } \\
\hline & \multicolumn{6}{|c|}{3} & \multicolumn{3}{|c|}{5} & \multicolumn{3}{|c|}{6} & \multicolumn{3}{|c|}{7} & \multicolumn{4}{|c|}{8} \\
\hline & w & B & $\mathbf{R}$ & W & B & $\mathbf{R}$ & w & B & $\mathbf{R}$ & w & B & $\mathbf{R}$ & W & B & $\mathrm{R}$ & w & B & $\mathbf{R}$ & D \\
\hline \multirow[t]{2}{*}{$\mathrm{T}_{0}$} & 0 & 0 & 0 & 0 & 0 & 2.0 & 5.0 & 2.0 & 8.0 & 8.0 & 6.0 & 13.0 & 12.0 & 10.0 & 13.0 & 12.0 & 12.0 & 13.0 & 11.0 \\
\hline & & & & & & \pm 1.0 & \pm 1.0 & \pm 1.0 & \pm 1.0 & \pm 1.0 & \pm 1.0 & \pm 2.0 & \pm 2.0 & \pm 2.0 & \pm 2.0 & \pm 2.0 & \pm 2.0 & \pm 2.0 & \pm 2.0 \\
\hline \multirow[t]{2}{*}{$\mathrm{T}_{5}$} & 2.0 & 2.0 & 6.0 & 8.0 & 5.0 & 12.0 & 26.0 & 19.0 & 36.0 & 37.0 & 29.0 & 47.0 & 44.0 & 37.0 & 47.0 & 44.0 & 43.0 & 47.0 & 43.0 \\
\hline & \pm 1.0 & \pm 1.0 & \pm 1.0 & \pm 1.0 & \pm 1.0 & \pm 1.0 & \pm 2.0 & \pm 2.0 & \pm 3.0 & \pm 3.0 & \pm 3.0 & \pm 3.0 & \pm 3.0 & \pm 3.0 & \pm 3.0 & \pm 3.0 & \pm 3.0 & \pm 3.0 & \pm 3.0 \\
\hline \multirow[t]{2}{*}{$\mathrm{T}_{10}$} & 14.0 & 11.0 & 14.0 & 36.0 & 30.0 & 40.0 & 47.0 & 43.0 & 51.0 & 59.0 & 51.0 & 67.0 & 71.0 & 62.0 & 71.0 & 71.0 & 63.0 & 71.0 & 65.0 \\
\hline & \pm 2.0 & \pm 2.0 & \pm 2.0 & \pm 3.0 & \pm 3.0 & \pm 3.0 & \pm 3.0 & \pm 3.0 & \pm 4.0 & \pm 4.0 & \pm 4.0 & \pm 4.0 & \pm 4.0 & \pm 4.0 & \pm 4.0 & \pm 4.0 & \pm 4.0 & \pm 4.0 & \pm 4.0 \\
\hline \multirow[t]{2}{*}{$\mathrm{T}_{15}$} & 8.0 & 7.0 & 7.0 & 21.0 & 18.0 & 26.0 & 41.0 & 30.0 & 42.0 & 41.0 & 37.0 & 42.0 & 41.0 & 37.0 & 42.0 & 41.0 & 37.0 & 42.0 & 40.0 \\
\hline & \pm 1.0 & \pm 1.0 & \pm 1.0 & \pm 2.0 & \pm 2.0 & \pm 2.0 & \pm 3.0 & \pm 3.0 & \pm 3.0 & \pm 3.0 & \pm 3.0 & \pm 3.0 & \pm 3.0 & \pm 3.0 & \pm 3.0 & \pm 3.0 & \pm 3.0 & \pm 3.0 & \pm 3.0 \\
\hline
\end{tabular}

Duration for acid scarification: $\mathrm{T}_{15}=15 \mathrm{~min}, \mathrm{~T}_{10}=10 \mathrm{~min}, \mathrm{~T}_{5}=5 \mathrm{~min}, \mathrm{~T}_{0}=$ no scarification. $\mathrm{W}=$ white light, $\mathrm{B}=$ blue light, $\mathrm{R}=$ red light, $\mathrm{D}=$ dark condition.

Table 5. Effects of various durations of acid scarification and different colours of light on percentage germination (mean \pm standard error) of eight-month-old seeds of Desmodium triflorum.

\begin{tabular}{|c|c|c|c|c|c|c|c|c|c|c|c|c|c|c|c|c|}
\hline \multirow{3}{*}{ Treatments } & \multicolumn{16}{|c|}{ Days after sowing } \\
\hline & \multicolumn{3}{|c|}{4} & \multicolumn{3}{|c|}{5} & \multicolumn{3}{|c|}{6} & \multicolumn{3}{|c|}{7} & \multicolumn{4}{|c|}{8} \\
\hline & W & B & $\mathbf{R}$ & W & B & $\mathbf{R}$ & W & B & $\mathbf{R}$ & W & B & $\mathbf{R}$ & W & B & $\mathbf{R}$ & D \\
\hline \multirow[t]{2}{*}{$\mathrm{T}_{0}$} & 0 & 0 & 0 & 5.0 & 2.0 & 9.0 & 11.0 & 7.0 & 16.0 & 21.0 & 17.0 & 23.0 & 21.0 & 20.0 & 23.0 & 19.0 \\
\hline & & int & & \pm 1.0 & \pm 1.0 & \pm 1.0 & \pm 2.0 & \pm 1.0 & \pm 2.0 & \pm 2.0 & \pm 2.0 & \pm 2.0 & \pm 2.0 & \pm 2.0 & \pm 2.0 & \pm 2.0 \\
\hline \multirow[t]{2}{*}{$\mathrm{T}_{5}$} & $9.0 \pm 1.0$ & $6.0 \pm 1.0$ & 11.0 & 14.0 & 8.0 & 16.0 & 34.0 & 19.0 & 34.0 & 42.0 & 33.0 & 44.0 & 42.0 & 37.0 & 44.0 & 39.0 \\
\hline & & & \pm 2.0 & \pm 2.0 & \pm 1.0 & \pm 2.0 & \pm 3.0 & \pm 2.0 & \pm 3.0 & \pm 3.0 & \pm 3.0 & \pm 3.0 & \pm 3.0 & \pm 3.0 & \pm 3.0 & \pm 3.0 \\
\hline \multirow[t]{2}{*}{$\mathrm{T}_{10}$} & 21.0 & 20.0 & 29.0 & 37.0 & 29.0 & 50.0 & 61.0 & 52.0 & 76.0 & 76.0 & 63.0 & 84.0 & 81.0 & 77.0 & 84.0 & 77.0 \\
\hline & \pm 2.0 & \pm 2.0 & \pm 3.0 & \pm 3.0 & \pm 3.0 & \pm 3.0 & \pm 4.0 & \pm 4.0 & \pm 4.0 & \pm 4.0 & \pm 4.0 & \pm 4.0 & \pm 4.0 & \pm 4.0 & \pm 5.0 & \pm 4.0 \\
\hline \multirow[t]{2}{*}{$T_{15}$} & 21.0 & 17.0 & 25.0 & 31.0 & 21.0 & 35.0 & 64.0 & 49.0 & 64.0 & 64.0 & 51.0 & 64.0 & 64.0 & 59,0 & 64.0 & 61.0 \\
\hline & \pm 2.0 & \pm 1.0 & \pm 2.0 & \pm 3.0 & \pm 2.0 & \pm 3.0 & \pm 4.0 & \pm 3.0 & \pm 4.0 & \pm 4.0 & \pm 3.0 & \pm 4.0 & \pm 4.0 & \pm 4.0 & \pm 4.0 & \pm 4.0 \\
\hline
\end{tabular}

Duration for acid scarification: $T_{15}=15 \mathrm{~min}, T_{10}=10 \mathrm{~min}, T_{5}=5 \mathrm{~min}, T_{0}=$ no scarification. $W=$ white light, $B=$ blue light, $R=$ red light, $\mathrm{D}=$ dark condition. 
Table 6. Effects of various submergence duration in water on percentage germination (mean \pm standard error) of nine-month old seeds of Alysicarpus vaginalis and Desmodium triflorum.

\begin{tabular}{lcccc}
\hline \multirow{2}{*}{$\begin{array}{l}\text { Submergence } \\
\text { duration (days) }\end{array}$} & Brick-red seeds & $\begin{array}{c}\text { Pellowish-brown } \\
\text { seeds }\end{array}$ & Brick-red seeds & $\begin{array}{c}\text { Yellowish-brown } \\
\text { seeds }\end{array}$ \\
\hline 0 (h) & $28.0 \pm 3.0$ & $9.0 \pm 1.0$ & $32.0 \pm 3.0$ & $11.0 \pm 2.0$ \\
1 & $34.0 \pm 3.0$ & $34.0 \pm 3.0$ & $38.0 \pm 3.0$ & $31.0 \pm 3.0$ \\
2 & $14.0 \pm 2.0$ & $56.0 \pm 4.0$ & $27.0 \pm 3.0$ & $60.0 \pm 4.0$ \\
3 & $12.0 \pm 2.0$ & $72.0 \pm 4.0$ & $14.0 \pm 2.0$ & $77.0 \pm 4.0$ \\
4 & $10.0 \pm 2.0$ & $70.0 \pm 4.0$ & $9.0 \pm 1.0$ & $58.0 \pm 4.0$ \\
5 & $7.0 \pm 1.0$ & $40.0 \pm 3.0$ & $2.0 \pm 1.0$ & $31.0 \pm 3.0$ \\
6 & 0 & $16.0 \pm 2.0$ & 0 & $12.0 \pm 2.0$ \\
\hline
\end{tabular}

Table 7. Effects of various durations of acid scarification and different colours of light on percentage germination (mean \pm standard error) of nine-month-old seeds of Axonopus compressus.

\begin{tabular}{|c|c|c|c|c|c|c|c|c|c|c|c|c|c|c|c|c|c|c|c|}
\hline \multirow{3}{*}{ Treatments } & \multicolumn{19}{|c|}{ Days after sowing } \\
\hline & \multicolumn{3}{|c|}{13} & \multicolumn{3}{|c|}{14} & \multicolumn{3}{|c|}{15} & \multicolumn{3}{|c|}{16} & \multicolumn{3}{|c|}{17} & \multicolumn{4}{|c|}{18} \\
\hline & w & B & $\mathrm{R}$ & W & B & $\mathbf{R}$ & W & B & $\mathbf{R}$ & W & B & $\mathbf{R}$ & w & B & $\mathbf{R}$ & W & B & $\mathbf{R}$ & D \\
\hline \multirow[t]{2}{*}{$\mathrm{T}_{0}$} & 0 & 0 & 4.0 & 5.0 & 3.0 & 10.0 & 11.0 & 10.0 & 12.0 & 15.0 & 14.0 & 16.0 & 17.0 & 15.0 & 16.0 & 17.0 & 15.0 & 16.0 & 16.0 \\
\hline & & & \pm 1.0 & $\neq 1.0$ & \pm 1.0 & \pm 2.0 & \pm 2.0 & \pm 2.0 & \pm 2.0 & \pm 2.0 & \pm 2.0 & \pm 2.0 & \pm 2.0 & \pm 2.0 & \pm 2.0 & \pm 2.0 & $\pm 2,0$ & \pm 2.0 & \pm 2.0 \\
\hline \multirow[t]{2}{*}{$\mathrm{T}_{5}$} & 11.0 & 7.0 & 19.0 & 19.0 & 12.0 & 25.0 & 25.0 & 19.0 & 30.0 & 32.0 & 29.0 & 32.0 & 32.0 & 30.0 & 32.0 & 32.0 & 30.0 & 32.0 & 27.0 \\
\hline & \pm 2.0 & \pm 1.0 & $\pm 2,0$ & \pm 2.0 & \pm 2.0 & \pm 2.0 & \pm 2.0 & \pm 2.0 & \pm 3.0 & \pm 3.0 & \pm 3.0 & \pm 3.0 & \pm 3.0 & \pm 3.0 & \pm 3.0 & \pm 3.0 & \pm 3.0 & \pm 3.0 & \pm 3.0 \\
\hline \multirow[t]{2}{*}{$\mathrm{T}_{10}$} & 20.0 & 11.0 & 27.0 & 32.0 & 25.0 & 36.0 & 40.0 & 37.0 & 45.0 & 41.0 & 39.0 & 45.0 & 41.0 & 42.0 & 45.0 & 41.0 & 42.0 & 45.0 & 37.0 \\
\hline & \pm 2.0 & \pm 2.0 & \pm 3.0 & \pm 3.0 & \pm 2.0 & \pm 3.0 & \pm 3.0 & \pm 3.0 & \pm 3.0 & \pm 3.0 & \pm 3.0 & \pm 3.0 & \pm 3.0 & \pm 3.0 & \pm 3.0 & \pm 3.0 & \pm 3.0 & \pm 3.0 & \pm 3.0 \\
\hline \multirow[t]{2}{*}{$\mathrm{T}_{15}$} & 10.0 & 10.0 & 12.0 & 18.0 & 18.0 & 21.0 & 23.0 & 24.0 & 21.0 & 23.0 & 24.0 & 21.0 & 23.0 & 24.0 & 21,0 & 23.0 & 24.0 & 21.0 & 21.0 \\
\hline & \pm 2.0 & \pm 2.0 & $\pm 2,0$ & \pm 2.0 & \pm 2.0 & \pm 2.0 & \pm 2.0 & \pm 2.0 & \pm 2.0 & \pm 2.0 & \pm 2.0 & \pm 2.0 & \pm 2.0 & \pm 2.0 & \pm 2.0 & \pm 2.0 & \pm 2.0 & \pm 2.0 & \pm 2.0 \\
\hline
\end{tabular}

Duration for acid scarification: $T_{15}=15 \mathrm{~min}, \mathrm{~T}_{10}=10 \mathrm{~min}, \mathrm{~T}_{5}=5 \mathrm{~min}, \mathrm{~T}_{0}=$ no scarification. $\mathrm{W}=$ white light, $\mathrm{B}=$ blue light, $\mathrm{R}=$ red light, $\mathrm{D}=$ dark condition.

Table 8. Effects of different concentrations of potassium nitrate on percentage germination (mean \pm standard error) of nine-month-old caryopses of Chrysopogon aciculatus.

\begin{tabular}{ccccc}
\hline $\begin{array}{c}\text { Concentration of } \\
\text { potassium nitrate (\%) }\end{array}$ & $\mathbf{2 3}$ & $\mathbf{2 4}$ & $\mathbf{2 5}$ & $\mathbf{2 6}$ \\
\hline 0.00 & $1.0 \pm 1.0$ & $3.0 \pm 1.0$ & $4.0 \pm 1.0$ & $4.0 \pm 1.0$ \\
0.25 & $7.0 \pm 1.0$ & $9.0 \pm 1.0$ & $10.0 \pm 2.0$ & $10.0 \pm 2.0$ \\
0.50 & $15.0 \pm 2.0$ & $16.0 \pm 2.0$ & $17.0 \pm 2.0$ & $17.0 \pm 2.0$ \\
0.75 & $8.0 \pm 1.0$ & $9.0 \pm 1.0$ & $9.0 \pm 1.0$ & $9.0 \pm 1.0$ \\
1.00 & $6.0 \pm 1.0$ & $6.0 \pm 1.0$ & $6.0 \pm 1.0$ & $6.0 \pm 1.0$ \\
\hline
\end{tabular}

ECOPRINT VOL 13, 2006 
The selected species of the present study had large seed output. These species also reproduce vegetatively during moist and warm season of the year. Shiew et al. (1988) have opined that the more successful species are those which exhibit a large seed output as well as capability of vegetative propagation, whereas species in which vegetative propagation is the only or dominant method of reproduction are mostly associated with more densely populated habitats and the later phases of plant succession. The importance of seeds is that the survival of plants under harsh conditions is connected mainly with germination mechanisms which ensure seedling development at the right time and in a suitable place (Gutterman 1993). All the species tested in this study have small seeds which is believed to be a feature of many species that form persistent soil seed banks (Grime et al. 1981, Fenner 1995) as small seeds have a better chance to enter into the soil easily than the larger ones.

Seeds vary greatly in their viability and longevity depending on the species and varieties as well as the conditions of harvest and storage (Bewley and Black 1994, Subba Rao et al. 1996, Hartmann et al. 1997). The seed storage condition seems to play an important role in determining the seed response when germination condition become ideal. The way by which particular environmental factors effect the seed bank during the period of dormancy could explain atleast the establishment stage, the distribution pattern of species (Epiner et al. 2005). In the present study, the freshly collected grass seeds had the highest viability which declined progressively as the storage duration increased. The $\mathrm{Br}$ seeds of the legumes behaved similarly to grass seeds, but storage up to three years had more or less no adverse effect on the viability of $\mathrm{Yb}$ seeds probably due to hard seed coat. In general, deterioration of seeds with ageing results in the loss of viability and vigour during storage which is usually due to the alteration in moisture content, changes in biochemical composition, and increased leaching of electrolytes and other low molecular weight substances during imbibition as opined by Hartmann et al. (1997).

The freshly collected seeds of all the species exhibited dormancy as they failed to germinate even after acid scarification and incubation under various light qualities, and temperature regime which permitted germination in older seeds. Seeds in soil seed bank can be either water permeable or water-impermeable. In each of these categories, seeds can be dormant but dormancy can be broken resulting in non-dormant seeds (Baskin and Baskin 2006). The seven-nine-month-old seeds without scarification or nutrient treatment exhibited germination in the order:D. triflorum $(23 \%)>A$. compressus $(17 \%)>A$. vaginalis $(13 \%)>C$. aciculatus (4\%). This finding is in agreement with the conclusion of Barbour et al. (1980) that seeds of a species forming persistent soil seed bank germinate in small number.

In this study, increase in water uptake by the acid scarified $\mathrm{Yb}$ seeds was 86 and $82 \%$, respectively in $A$. vaginalis and $D$. triflorum, whereas water uptake by the acid scarified $\mathrm{Br}$ seeds of the legumes and those of grass caryopses occurred in the order:A. compressus $(15 \%)>A$. vaginalis $(12 \%)>D$. triflorum $(7 \%)>C$. aciculatus $(6 \%)$ in comparison to water imbibition without acid scarification. In general, there are four stages of germination:(1) hydration or imbibition, during which water penetrates into the embryo and hydrates proteins and other colloids; (2) the formation or activation of enzymes, leading to increased metabolic activity; (3) elongation of radicle cells followed by the emergence of radicle from the seed coat; and (4) subsequent growth of 
the seedling. Dormancy can be brought about by interference with any of the first three stages, and covering layers around the embryo - the endosperm, the seed coat, and the fruit coat - play a decisive role in this interference. In some, these layers prevent the entry of water and/or oxygen, in others, they prevent emergence of radicle by acting as a mechanical barrier; while in others, they apparently prevent leaching of inhibitors out of the embryos or contain inhibitors themselves.

Seed coat impermeability (displayed by the $\mathrm{Yb}$ seeds of $A$. vaginalis and $D$. triflorum), a characteristic feature of most leguminous speices, is a delaying mechanism which prevents germination under conditions that might prove to be unsuitable for establishment (Cavanagh 1987, Baskin and Baskin 1989, Tybirk 1991, Teketay 1997). The hard seed coat has several advantages, in that, it allows endozoic dispersal, recolonization after fire and helps the seeds to withstand unfavourable conditions such as heat, drought, digestive juice as well as mechanical damage (Tybirk 1991).

In this study, seven-nine month old seeds of $A$. compressus, A. vaginalis and D. triflorum had the best percentage of germination when acid scarified for $10 \mathrm{~min}$ and incubated under red light. Incubation of seeds under white light had promotive effect next only to red light in $A$. vaginalis and $D$. triflorum, whereas blue light and dark condition had little inhibitory effects on germination in the test species. The amount of chlorophyll that covers the embryo as the seed ripens is specially important in determining whether or not seeds of a given species will be photodormant (Cresswell and Grime 1981). In general, embryos that are covered during ripening by maternal tissues that contain high amount of chlorophyll require light to germinate, whereas those that are covered by maternal tissues with little or no chlorophyll do not. It may be the reason that different light colours had no effect on germination in C. aciculatus.

In natural sunlight (white light), red wavelengths dominate over far-red at a ratio of 2:1, so that the phytochrome tends to remain in the active $\mathrm{P}_{\mathrm{fr}}$ form. Under a foliage conopy, far-red is dominant as most of the blue, red, and some of the green wavelengths are removed by leaves through photosynthesis and reflectance, and the red/far-red ratio may be as low as $0.12: 1.00$ to $0.70: 1.00$, which can inhibit seed germination. Red light penetrates less deeply into the soil than far-red, so that the red/far-red ratio becomes lower with depth until eventually darkness is complete. Imbibed light sensitive seeds buried in the soil will remain dormant until such time as the soil is cultivated or disturbed so as to expose them to light (Hartmann et al. 1997).

Teketay (1998) has reported germination in some photodormant Solarium spp. in the dark under the average amplitude of temperature fluctuation around $17^{\circ} \mathrm{C}$. In this study also seeds of A. compressus, $A$. vaginalis and $D$. triflorum germinated in the dark considerably under the average amplitude of temperature fluctuation around $10^{\circ} \mathrm{C}$. This suggests that the seeds are capable of germinating while still buried in the soil if the gap is formed in the vegetation leading to marked amplitude in the fluctuation of temperature. The amplitude of alternating temperatures beneath intact vegetation has been shown to be much lower than that in gaps (Vazquez-Yanes and Orozco-Segovia 1982), since the insulating values of vegetation cover serve to buffer temperature changes. The response of alternating temperatures could also help seeds of the test species to sense their depth of burial in the soil since the soil itself acts as a buffer of temperatrue changes (Fenner 1995). Deeply buried seeds will be prevented from germination since 
they will experience smaller temperature fluctuation compared to those buried nearer to the surface.

In nature, a seed bank ensures that not all the seeds for a species germinate in a single year. This is insurance against years where flowering and fruiting may not occur for some catastrophic environmental reason. Some seeds remain dormant in the seed bank for decades. Some species take this concept one step further. They produce polymorphic seeds. In this case, seeds produced on the same plant or different plants in a population have different physical appearance, and dormancy. One seed is for immediate germination and other for the seed bank, and future generation (Hartmann et al. 1997). Such a trend was also exhibited by the legumes in the present study.

Hussain and Ilahi (1999) reported enhanced and early germination of Acacia nilotica seeds under flooded water and similar observation was recorded in Acacia megnum seeds by Chacko and Pillai (1995). The reason for this enhancement is that water improves imbibition by softening the seed coat to facilitate germination. In this study, very high rate $(77$ and $72 \%$, respectively in $D$. triflorum and $A$. vaginalis) of germination was recorded in $\mathrm{Yb}$ seeds of the legumes subjected to submergence in water for three days as pretreatment. The $\mathrm{Br}$ seeds of the legumes had better germination (38 and $34 \%$, respectively in $D$. triflorum and $A$. vaginalis) after receiving submergence treatment just for 24 h. Good response of seeds to flooded water treatment is an advantage in that the method is simple, convenient, cheap and requires little skill. As a result, it can be practically applied for small and large-scale seedling production in nurseries.

The present study showed that the seeds of $C$. aciculatus are nitrophilous as they exhibited a remarkable enhancement of germination when treated with $0.5 \%$ solution of potassium nitrate.
Nitrates are known to effect seed germination by overcoming the light and chilling requirements of seeds (Wareing 1969) presumably through increasing nutrient metabolism and embryo growth (Pathak et al. 1974). The caryopsis of $C$. aciculatus bears an awn which may facilitate germination by finding a suitable (nitrogen-rich) microsite, orienting the seed for optimal moisture uptake and anchoring it against the thrust of emerging radicle (Peart 1984, Peart and Clifford 1987).

The information generated from this study can make a practical contribution to the design of appropriate reseeding methods for the degraded native rangelands, watersheds, roadsides and lawns, etc where the cover of the test species is required.

\section{ACKNOWLEDGEMENTS}

Authors are thankful to Prof. S.D. Joshi, former Head, Central Department of Botany, Tribhuvan University, and Campus Chief, Post Graduate Campus, Tribhuvan University, Biratnagar for the facilities.

\section{REFERENCES}

Barbour, M.G., J.H. Burk and W.D. Pitts. 1980. Terrestrial Plant Ecology. The Benjamin/ Cummings Publishing Company, Inc., California, USA.

Baskin, J.M. and C.C. Baskin. 1989. Physiology of seed dormancy and germination in relation to seed bank ecology. In: Ecology of Soil Seed Banks. (eds.) Leek, M.A., V.T. Parker and R.L. Simpson). Academic Press, San Diego, pp. 5366.

Baskin, J.M. and C.C. Baskin. 2006. Symposium: The natural history of soil seed banks of arable land. Weed Science 54:549-557. 
Bewley, J.D. and M. Black. 1994. Seeds: Physiology of Development and Germination (2nd edn.) Plenum Press, New York and London.

Cavanagh, T. 1987. Germination of hard seeded species (order Fabales). In: Germination of Australian Native Plant Seed. (ed.) Langkamp, P. Amira, Melbourne/Sydney, pp. 58-70.

Chacko, K.C. and P.K.C. Pillai. 1995. Effect of some pre-sowing treatments on germination of Acacia megnum seeds. Bangladesh J. Forest Sci. 24:70-73.

Copeland, L.O. 1976. Principles of Seed Science and Technology. Burgess Publishing Company, Minnesota.

Cresswell, E.G. and J.P. Grime. 1981. Induction of a light requirement during seed development and its ecological consequences. Nature 291:583 - 585 .

Epiner, J.L., L.V. Garcia and L. Clement. 2005. Seed storage conditions change the germination pattern of closed growth plants in mediterranean salt marshes. American Journal of Botany 92:1094-1101.

Fenner, M. 1995. Ecology of seed banks. In: Seed Development and Germination. (eds.) Kigel, J. and G. Galili. Marcel Dekker, Inc., New York. pp. 507-528.

Grime, J.P., G. Mason, A.V. Curtis, J. Rodman, S.R. Band, M.A.G. Mowforfh, A.M. Neal and S. Shaw. 1981. A comparative study of germination characteristics in a local flora. Journal of Ecology 69:1017-1059.

Gutterman, Y. 1993. Seed Germination in Desert Plants. Springer-Verlag, Berlin.

ECOPRINT VOL 13, 2006
Hartmann, H.T., D.E. Kester, F.T. Davies (Jr.) and R. L. Geneve. 1997. Plant Propagation: Principles and Practices (6th edn.). PrenticeHall, Inc., New Jersey.

Hussain, F. and I. Ilahi. 1999. Acid scarification improves germination of Acacia nilotica spp. nilotica. Pakistan J. Plant Sci. 5(1):69-76.

Jha, S. and P.K. Jha. 2000. Seasonal changes in importance value index (IVI) and biomass in a lowland Nepalese grassland community. Geobios 27(1):25-30.

Jha. S., N. Limbu and P.K. Jha. 1999. Ecology of Alysicarpus vaginalis (L.) DC. Scientific World 1(1):43-47.

Misra, R. 1968. Ecology Workbook. Oxford and IBH Publishing Company, New Delhi.

Pathak. P.S., R. Debroy and P. Rai. 1974. Autecology of Leucaena leucocephala (Lam.) De Wit. I. Seed polymorphism and germination. Tropical Ecology 15(1-2):1-10.

Peart, M.H. 1984. The effect of morphology, orientation and position of grass diaspore on seedling survival. Journal of Ecology 72:437543.

Peart, M.H. and H.T. Clifford. 198\%. The influence of diaspore morphology and soil surface properties on the distribution of grasses. Journal of Ecology 75:569-576.

Shiew, F.T., A.N. Rao and Y.C. Wee. 1988. Reproductive biology of weeds in Singapore. $J$. Singapore Nat. Acad. Sci. 17:74-93.

Subba Rao, L.V., S. Kumar and G. Vanisree. 1996. Genetic variability for seedling charactristics among rice (Oryza sativa L.) cultivars. Seed Res. 24:124-128. 
Teketay, D. 1997. Germination ecology of Acacia negrii, an endemic multipurpose tree from Ethiopia. Tropical Ecology 38(1):39-46.

Teketay, D. 1998. Environmental factors that control the germination of five Solanum species from Ethiopia. Tropical Ecology. 39(1):79-87.

Tybirk, K. 1991. Regeneration of Woody Legumes in Sahel. AAU Report 27, Aarhus University Press, Aarhus.

Vazqueq-Yanes, C. and A. Orozeo-Segovia. 1982. Germination of the seeds of a tropical rain forest shrub. Piper hispidum Sw. (Piperaceae) under different light qualities. Phyton 42:143149.

Wareing, P.E. 1969. Germination and dormancy. In: Physiology of Plant Growth and Development. (ed.) M.B. Wilkins. McGraw Hill, New York, pp. 605-644.

Zobel, D.B., P.K. Jha, M.J. Behan and U.K.R. Yadav. 1987. A Practical Manual for Ecology. Ratna Book Distributors, Kathmandu. 